\title{
DIREITO, POLÍTICA E RECONHECIMENTO: APONTAMENTOS SOBRE KARL MARX E A CRÍTICA AO DIREITO
}

\section{LAW, POLITICS AND ACKNOWLEDGMENT: NOTES ON MARX AND THE CRITIC OF LAW}

\author{
Vitor Bartoletti Sartori*
}

\begin{abstract}
RESUMO
Tendo por essencial a concepção de Marx segundo a qual "o Direito não é mais que o reconhecimento oficial do fato", tratar-se-á do modo pelo qual a categoria do "reconhecimento" (Anerkennung) se apresenta no tratamento marxiano acerca da esfera jurídica. Em meio a isso, pretende-se traçar aspectos importantes da diferença específica existente entre as esferas da Política e do Direito. Enquanto, para o autor de $O$ capital, a primeira se mostra como um campo em que há alguma possibilidade da explicitação da natureza antagônica da sociedade civil-burguesa (bürgerliche Gesellschaft), ou seja, um terreno que pode levar, com as devidas mediações, à centralidade da luta de classes, no Direito isso parece, em Marx, como algo muito mais difícil de ocorrer, na medida mesma em que a noção de reconhecimento vem à tona.
\end{abstract}

\section{PALAVRAS-CHAVE}

Marx. Direito. Reconhecimento. Política.

\begin{abstract}
Taking in account the Marxian affirmation that says that "Law is nothing else than the official acknowledgment of the fact", we intend to deal with the relationship between Law and acknowledgment (Anerkennung), having in mind the heterogeneity of Politics and Law. The first may present itself as a field more likely to make explicit the contradictions of bourgeois civil society (bürguerliche Gesellschaft), mainly centered in class struggle; Law, on the other hand, according to Marx, tends to be a field in which this is much less likely to occur.
\end{abstract}

\section{KEYWORDS}

Marx. Law. Acknowledgment. Politics.

\footnotetext{
* Bacharel em Direito pela USP, Mestre em História pela PUCSP, Doutor em Filosofia e Teoria Geral do Direito pela USP. Professor Adjunto da Faculdade de Direito da UFMG (Belo Horizonte, MG, Brasil). E-mail: vitorbsartori@gmail.com
} 


\section{INTRODUÇÃO}

Tendo em conta principalmente aquilo que parece ter mais potencial no "terreno do Direito” (Rechtsboden) - a saber, a própria valorização dos “direitos do homem” -, procuraremos neste texto desenvolver a relação existente entre a sociedade civil-burguesa (bürgerliche Gesellschaft) e o reconhecimento (Anerkennung) de direitos no pensamento de Karl Marx. Trataremos do tema na medida em que importantes autores como Axel Honneth vêm trazendo à tona a relação entre reconhecimento e Direito.

Segundo esses autores, poderia haver, inclusive, uma postura contrária à reificação (Versachelichung) das relações sociais a partir da centralidade da noção de reconhecimento no desenvolvimento de uma teoria social de talhe crítico (HONNETH, 2012) ${ }^{1}$. Aqui, no entanto, procuraremos mostrar que o modo como a questão aparece em Marx é bastante mais mediado, sendo preciso considerar a relação entre Direito, reificação e reconhecimento na medida em que o próprio modo pelo qual o campo jurídico aparece na teoria do autor de $O$ capital tem consigo, não tanto um posicionamento crítico ao existente, mas algo que pode levar à naturalização das relações sociais de produção subjacentes ao "terreno do Direito".

\section{SOBRE A NECESSIDADE DA COMPREENSÃO DA POSIÇÃO DO DIREITO NA OBRA DE MARX}

Ao se tratar do Direito em Marx, bem como da política, um primeiro apontamento, que pode parecer um “balde de água fria”, precisa ser trazido à tona já com algum cuidado. Na obra de 1845, Ideologia alemã, Marx e Engels dizem explicitamente que a história é um processo unitário que abarca a totalidade das relações sociais, tendo como parte de seu processo constitutivo, entre outras esferas, a política, o Direito e a ideologia em geral, de modo que, a rigor, "não há história da política, do Direito, da ciência etc., da arte, da religião etc.” (MARX; ENGELS, 2007, p. 77). Ou seja, tanto o tratamento da “ciência política”, quanto da "ciência do Direito" ou da "teoria do Direito” aparecem, em grande parte, como algo que, em verdade, poderia ser visto por Marx como marcado por um forte grau de fetichização e por um hipostasiar inaceitável; veja-se: não que essas áreas, bem compreendidas, não possam trazer um conhecimento que, em medida considerável, possa ser importante para a compreensão da especificidade e particularidade de cada esfera do ser social que se trata; segundo os autores, para que se compreenda a realidade efetiva (Wirklichkeit) mesma da sociedade capitalista, não se pode prescindir de conhecimentos que tenham consigo a

\footnotetext{
${ }^{1}$ Para uma visão bastante positiva do pensamento de Honneth no Direito, Cf. GOMES; CATTONI DE OLIVEIRA, 2014.
}

Revista da Faculdade de Direito - UFPR, Curitiba, vol. 61, n. 2, maio/ago. 2016, p. 203 - 233 
importância que adquire, por exemplo, o aspecto jurídico em momentos decisivos, como os momentos de tensão social em que a própria noção de “direitos do homem” passa a parecer ser algo, em si, "socialista” - como o momento tratado por Marx em O 18 Brumário de Luís Bonaparte. No entanto, há de se enfocar: não há em Marx uma teoria do Direito. Este último só aparece em correlação necessária com o movimento da própria realidade social, sendo ele um momento constitutivo desta, conformando aquilo que o autor de $O$ capital chamou de "superestrutura jurídica e política” (juristischer und politischer Überbau) (MARX, 2009, p. 47). E essa questão precisa ser vista com bastante cuidado, pois já foi tratada de modo bastante unilateral (LUKÁCS, 2013)².

Sobre isto, tem-se um duplo aspecto a ser destacado: de um lado, aquilo que vem a caracterizar, seja o Direito, seja a política, parece ser sua conexão com as relações sociais de produção (o que, em Marx, é verdadeiro, mas, por si só, não basta para que se trate de compreender a teoria do autor de $O$ capital); doutro lado, há de se reconhecer que tanto Direito como política nunca podem ser simples epifenômenos da esfera das relações sociais de produção (LUKÁCS, 2013; SARTORI, 2014b). Esse duplo aspecto deve sempre ser destacado para que não se incorra em erros gêmeos, que, seguindo o pensamento marxiano, precisariam ser evitados: de um lado, corre-se o risco de deixar de apreender a real e efetiva especificidade de cada esfera social caso se reduza o Direito e a política a reflexos inertes de uma "infraestrutura”, dado que a premissa marxiana (a relação entre estrutura econômica da sociedade e superestrutura), assim, corre o risco de ser elevada ao patamar de conclusão; noutro polo, com uma espécie de hipostasia, para que usemos a dicção de Marx e de Engels acerca da história, parece que se toma como, em si subsistentes, a "história da política” e a "história do Direito”, o que seria um erro patente. Não se poderia, de modo algum, pois, contentar-se em simplesmente estabelecer a relação entre as esferas política e jurídica com as relações sociais de produção; doutro lado, seria igualmente unilateral deixar de considerar a indissociabilidade entre estas esferas. Vejamos então com mais cuidado a questão nos autores.

Uma primeira questão a se notar quando se tem como referência o pensamento marxiano diz repeito à impossibilidade de uma valorização da especialização crescente dos estudos jurídicos e políticos $^{3}$. Faz-se, assim, necessário destacar que Marx e Engels apontaram (é verdade que em uma

\footnotetext{
${ }^{2}$ Tal aspecto unilateral decorre de uma compreensão em que a "superestrutura" tem uma relação mecânica com a "infraestrutura”, colocando-se como um simples epifenômeno da última. Neste sentido, haveria uma relação passiva do Direito em relação àquilo que lhe dá base, sendo deixada de lado a discussão acerca da especificidade do Direito. A grande questão passaria a ser apreender que classe social está representada nele. Como veremos neste texto, a questão é bastante mais meandrada, sendo preciso compreender a especificidade do Direito, bem como o modo como se dá sua relação com o campo político e com o campo econômico.

${ }^{3}$ Ranieri Carli (2013) analisou, a partir de Lukács (1959), a questão em relação ao surgimento da sociologia. Seu raciocínio, parte da análise do processo de especialização que dá ensejo às ciências parcelares no final do século XIX e no começo do século XX. Seria ainda necessário um estudo semelhante no que toca o Direito, embora tenha-se tentado dar os primeiros passos neste sentido no texto A questão da crítica ao Direito à luz da obra madura de György Lukács
} 
passagem riscada da Ideologia alemã $\tilde{a}^{4}$ justamente que "conhecemos apenas uma ciência, a ciência da história” (Wir kennen nur eine einzige Wissenschaft, die Wissenschaft der Geschichte) (MARX; ENGELS, 2002, p. 107). Ou seja, não haveria, a rigor, como valorizar um tratamento do Direito ou da política que não confluíssem com uma "ciência da história”, a qual tratasse do complexo desenvolvimento real da efetividade (Wirklichkeit) enquanto um processo unitário marcado pela relação entre a "totalidade das relações de produção”, “a estrutura econômica da sociedade”, a “superestrutura jurídica e política”, “formas determinadas de consciência” - em suma, todo o “processo de vida intelectual, político e social” (MARX, 2009, p. 47) 5

Nesse sentido, mesmo a “ciência da história” como está conformada, preponderantemente, hoje em dia - com uma grande influência do pós-estruturalismo e de análises que não deixam de remeter ao culturalismo, para não mencionar o uso de metodologias quantitativas de modo exacerbado - estaria, se tomarmos como referência a obra marxiana, em um campo um tanto quanto restrito (DOSSE, 1992). A “ducha de água fria” mencionada conforma-se, assim, ao passo que, em parte considerável, aquilo que é produzido dificilmente passaria pelo crivo de Marx, e isso se dá mesmo quando se trata de produções de marxistas renomados no campo da política e do Direito.

Sobre este ponto vale lembrar, certamente, a posição de Marx segundo a qual “a única coisa que sei é que não sou um marxista” (MARX; ENGELS, 2010, p. 277). No entanto, não é tanto disto que se trata quando procuramos adentrar nesse ponto que estamos destacando aqui. Se o autor de $O$ capital não era "um marxista”, talvez seja difícil não enquadrar aqueles que seguem seus passos como tais, mesmo que se trate de alguém de grande proximidade com Marx, como o próprio Engels (MUSSE, 2002; PAÇO CUNHA, 2015; SARTORI, 2015a). Ou seja, de algum modo, ao utilizar a obra de Marx como auxílio na compreensão de questões políticas e jurídicas, sempre, até certo ponto, coloca-se em uma posição que vai contra a letra do próprio Marx, que não foi “um marxista”. O modo como se faz isso, no entanto, não é indiferente (SARTORI, 2015a) ante o modo de lidar com a complexidade da realidade efetiva mesma, sendo necessário um cuidado todo especial com o modo pelo qual o autor de $O$ capital trata das distintas esferas do ser social. E isso

(SARTORI, 2015d). Para o que tratamos aqui, destacamos somente que há uma clara crítica à compreensão parcelar da realidade em Marx já que a história seria um processo unitário e, neste sentido, "não há história da política, do Direito, da ciência, etc., da arte, da religião etc.”

${ }^{4}$ A passagem, embora riscada, tem o mesmo espírito das demais passagens do texto. É muito difícil saber se na versão final do texto a passagem seria incluída ou não, já que, ao final, o escrito de Marx e Engels não foi publicado.

${ }^{5}$ Os próprios autores sabem que a tarefa que se propõem não é, nem pode, ser simples. Dizem que "toda concepção histórica existente até então ou tem deixado completamente desconsiderada essa base real da história, ou a tem considerado apenas como algo acessório, fora de toda e qualquer conexão com o fluxo histórico.” (MARX; ENGELS, 2007, p. 43) E, nesta passagem, também, resta clara a crítica à hipostasia de quaisquer instituições e formas de práxis social, sendo necessário, na apreensão do real, considerar o próprio modo pelo qual, ao final, os homens fazem a si mesmos, no processo histórico, mediante condições legadas pelo passado. (MARX, 1997) 
ocorre mesmo que, por vezes, possa ser desagradável àquele que procura uma posição mais “progressista” para “aplicação do marxismo”, seja no "terreno do Direito”, seja em meio ao tratamento crítico da esfera política. A noção mesma de "aplicação" tende a remeter a uma concepção de "método" que não deixa de apresentar alguma unilateralidade ao trazer um modo no qual a realidade mesma deveria se enquadrar. E, como destacou José Chasin em seu estudo sobre Marx, "se por método se entende uma arrumação operativa, a priori, da subjetividade, consubstanciada por um conjunto normativo de procedimentos, ditos científicos, com os quais o investigador deve levar a cabo seu trabalho, então não há um método em Marx.” (CHASIN, 2009, p. 89)

É bom se ter em mente, ao mesmo tempo, a impossibilidade de hipostasiar as distintas esferas do ser social (dando a elas um tratamento autônomo) e a vedação - igualmente necessária a uma compreensão linear da dialética entre aquilo que foi, por assim dizer, "classicamente" chamado de "base” e de "superestrutura”. Assim, para Marx e Engels, ao se ter em conta a questão da relação entre as diferentes esferas do ser social, é de fundamental importância que se tenha em conta o modo pelo qual a efetividade (Wirklichkeit) se coloca histórica e objetivamente (até mesmo porque, para Marx, “um ser não objetivo é um não-ser”) (MARX, 2004, p. 127), e não simplesmente como um “modelo" a ser “aplicado” (CHASIN, 2009; LUKÁCS, 2010) ou mimetizado.

Para que tenhamos em conta, com o cuidado devido, esse aspecto, vale trazer uma passagem bastante conhecida, e muitas vezes vista com uma superficialidade e ingenuidade cândidas:

\begin{abstract}
A totalidade destas relações de produção [Die Gesamtheit dieser Produktionsverhältnisse] constitui a estrutura econômica [ökonomische Struktur] da sociedade, a base real [reale Basis] sobre a qual se eleva uma superestrutura jurídica e política [juristischer und politischer Überbau] à qual correspondem formas sociais determinadas de consciência [bestimmte gesellschaftliche Bewusstseinformen]. O modo de produção da vida material [Produktionsweise des materialen Lebens] condiciona [dedingt] o processo de vida intelectual, político e social [sozialen, polischen und geistgen Lebensprozess]. (MARX, 2009, p. 47)
\end{abstract}

Por mais que muitos "marxistas", mesmo que de modo subjetivamente honesto, tenham utilizado a referida passagem para a defesa de posições bastante questionáveis (relacionadas, geralmente, a uma compreensão bastante unilateral da determinação social), a primeira questão que é trazida à tona é o fato de a própria "estrutura econômica” (que, não raro, fora utilizada como uma espécie de "chave mágica” pelos referidos “marxistas”) trazer consigo a complexidade presente na “totalidade das relações de produção”, que, por seu turno, é objeto de um livro nada esquemático e simples do próprio Marx, a saber, O capital - havendo tratamento desse tema em outros textos de 
Marx, como os Grundrisse, por exemplo. Ou seja, para se analisar ainda que minimamente o que está em jogo ao se tratar de “estrutura econômica” já há a necessidade de compreender a "anatomia” da sociedade civil-burguesa como um todo, o que passa longe de ser simples. Se isto é expresso em Marx no sentido de que esta “anatomia” “deve ser procurada na economia política” (MARX, 2009, p. 47), ele vai ainda mais longe, ao afirmar que é necessária uma crítica à própria economia política, como o subtítulo da obra-mestra do autor indica ${ }^{6}$. Nesse sentido, qualquer tratamento do Direito e da política precisa ter, no mínimo, um cuidado decisivo ao relacionar os mesmos com o processo social que está expresso na “estrutura econômica”.

Ou seja, mesmo que se trate da influência das relações sociais de produção no ser do Direito é necessário, em verdade, muito cuidado. As primeiras se conformam de tal modo que a “base real” nunca pode ser reduzida a um “princípio interpretativo” ou metódico (CHASIN, 2009); não se trata também de qualquer modelo heurístico a ser utilizado para compreender os mais distintos “objetos” de cada ciência parcelar - a "base real” de que fala Marx é o solo sobre o qual se colocam, no sentido mais amplo, a produção e a reprodução dos próprios homens, tendo-se em conta a complexa relação entre indivíduos, natureza e sociedade (LUKÁCS, 2013). Esses indivíduos só se conformam enquanto individualidades ao passo que fazem a sua própria história em circunstâncias que não são livremente escolhidas por eles mesmos, mas legadas pelo passado. Trata-se do campo de escolha entre distintas alternativas colocadas pelo passado no cotidiano dos homens mesmo, e somente assim se pode falar do condicionamento que sugere o autor alemão ${ }^{7}$.

Sem ter em conta este panorama, mesmo aquilo que normalmente é dito sobre o Direito em alguns meios marxistas (a indissociabilidade entre Direito e relações sociais de produção) pode passar mal compreendido. Mesmo que se tenha a relação da "forma jurídica" com a "forma mercantil”, como em Pachukanis, por exemplo, as coisas, dependendo do modo como isso seja feito, não melhoram substantivamente, caindo-se em uma espécie de análise analógica que aproxima o Direito àquilo que se passa na esfera das relações sociais de produção ${ }^{8}$ (SARTORI, 2015b; PAÇO

\footnotetext{
${ }^{6}$ Para um tratamento cuidadoso das implicações disso para o estudo do Direito, vale conferir o texto Teoria geral do direito e marxismo de Pachukanis como crítica marxista ao direito (SARTORI, 2015b)

${ }^{7}$ Marx é muito claro sobre este aspecto em uma famosa passagem do 18 Brumário de Luis Bonaparte: “os homens fazem a sua própria história, mas não a fazem segundo a sua livre vontade; não a fazem sob circunstâncias de sua escolha e sim sob aquelas com que se defrontam diretamente, legadas e transmitidas pelo passado. A tradição de todas as gerações mortas oprime como um pesadelo o cérebro dos vivos.” (MARX, 1997, p. 21)

${ }^{8}$ Pachukanis é sem dúvida um grande autor ao se ter em mente a compreensão marxista do Direito. Sua obra vem sendo objeto de importante debate, como indica, por exemplo, a publicação de dossiês sobre o autor, como aquele publicado na revista Verinotio. A variedade de posições presentes do dossiê é grande. No entanto, resta claro em todos os textos do dossiê que a relação entre "forma jurídica” e “forma mercantil” precisa ser compreendida com bastante cuidado no autor. Caso isso não ocorra, e se tome acriticamente a conclusão do autor soviético como ponto de partida, corre-se o risco de incorrer em algum dos "erros gêmeos” que apontamos acima.
} 
CUNHA, 2014). Também nesse sentido, a análise da própria posição de Marx nos parece ser importante.

Isso posto, vale continuar e averiguar o modo pelo qual Marx passa pela "superestrutura”, expressão essa que, como mencionado, também fora bastante vulgarizada (LUKÁCS, 2010, 2012, 2013). A questão, não raro, também suscitou muitos problemas. Principalmente, na medida em que o aspecto "superestrutural” foi considerado como "epifenomênico", a questão se colocou em relevo (de modo bastante negativo, diga-se de passagem), deixando-se de ter em conta que não poderiam ser, tanto Direito quanto política, simples reflexos fotográficos de relações sociais de produção de uma determinada época, ao mesmo tempo que nunca poderiam ser dissociados das mesmas. Certamente, Marx considerou estas formas sociais como “formas ideológicas” (ideologischen Formen) ${ }^{9}$; com isso, alguns, apressadamente, poderiam apontar que Direito e política, ao final, seriam espécies de “falsa consciência”, incapazes de levar a qualquer forma de atividade (Tätigkeit) capaz de ter alguma efetividade - tal compressão acerca da ideologia, vale destacar, é bastante corrente (CHAUI, 1979).

Isso, porém, vai contra a própria continuidade da passagem marxiana em que o autor de $O$ capital diz que se trata, em verdade, de "formas ideológicas, sob as quais os homens adquirem consciência desses conflitos” (MARX, 2009, p. 46) (ideologischen Formen, worin sich die Menchen dieses Konflikts bewusst werden und inh ausfachten $)^{10}$. Ou seja, mesmo o modo como os homens se relacionam por meio de “formas ideológicas” não é essencialmente marcado, necessária e inelutavelmente, por uma espécie de “falsa consciência” (LUKÁCS, 2013; VAISMAN, 2010); por meio delas mesmas, há a possibilidade de as pessoas "adquirirem consciência” e, nesse sentido, a própria práxis social pode se embasar naquilo que advém - também, mas não só - da tomada de consciência que passa pelo Direito e pela política, mesmo que esses sejam, como pretendemos explicitar posteriormente, “formas ilusórias” (MARX; ENGELS, 2007) ${ }^{11}$. Tanto por meio do

\footnotetext{
${ }^{9}$ A expressão encontra-se justamente em meio ao famoso prefácio de 1859 de Para uma crítica da economia política. Ela remete também a uma questão importante que, infelizmente, não pode ser analisada aqui com todo o cuidado: tratase daquilo que os autores althusserianos chamam de "materialidade das ideologias" (Cf. BATISTA, 2015). A questão é delineada ao passo que algo que se coloca como um veículo da expressão, inclusive subjetiva, passa por relações sociais existentes no plano do ser, como as relações jurídicas. O Direito, assim, por mais que seja uma "forma ideológica" tem uma conformação concreta no plano do ser. Um modo distinto do althusseriano de passar pela questão foi dado por Lukács (2013), tendo-se enfatizada justamente a relação existente entre a conformação concreta do aparato jurídico (indissociável do estatal segundo o autor) e aquele da ideologia jurídica. (Cf. SARTORI, 2010) Em ambos os casos temse que as "formas ideológicas" não são simples expressões ideais das relações sociais de uma época, mas também o veículo por meio do qual, ao tomar consciência acerca destas relações sociais, em meio a relações concretas, tem-se uma tomada de posição quanto à realidade social.

${ }^{10}$ Para um tratamento cuidadoso da questão da ideologia, Cf. VAISMAN, 2010.

${ }^{11}$ Neste ponto, há de se destacar que o fato de se tratar de uma forma ilusória não se opõe à possibilidade de uma real apreensão dos fenômenos sociais em determinadas circunstâncias. Para um tratamento cuidadoso da questão cf. LUKÁCS, 2010, 2012, 2013. Para uma análise bastante detida em solo brasileiro cf. FORTES, 2013.
} 
Direito quanto da política tem-se o desenvolvimento de “formas determinadas de consciência”, de tal feita que o modo pelo qual o "processo de vida intelectual, político e social” é condicionado pelo “modo de produção da vida material” traz como possibilidade algumas alternativas concretas, as quais, em verdade, só podem se tornar efetivas por meio da atuação consciente que, mediante “formas ideológicas”, os homens operam na realidade efetiva (SARTORI, 2015c). Ou seja, ao seguir aquilo que Marx diz é possível, também pelo Direito e pela política, que os homens tomem consciência acerca da efetividade mesma, sendo possível, assim, com as mediações necessárias, chegar-se a uma práxis que opere tendo em conta as determinações mesmas da realidade efetiva.

O modo como isso pode se dar será visto à frente. Agora, pois, devemos explicitar alguns pontos que precisam ser trazidos à luz caso se busque compreender com rigor e cuidado o modo pelo qual aparecem a política e o Direito em Marx.

\section{MARX E A CRÍTICA DA POLÍTICA}

Antes de qualquer posicionamento mais concreto sobre o tema que aqui procuramos tratar, é preciso que se diga - novamente, não sem uma “ducha de água fria” - que, em Marx, política e Estado não são vistos como capazes de reconciliar os antagonismos advindos da estrutura objetiva da sociedade civil-burguesa; primeiramente, o autor de $O$ capital diz explicitamente, nas Glosas Críticas Marginais ao Artigo “O Rei da Prússia e a Reforma Social” de Um Prussiano ${ }^{12}$, que “quanto mais unilateral, isto é, quanto mais perfeito é o intelecto político, tanto mais ele crê na onipotência da vontade e tanto mais é cego frente aos limites naturais da vontade” (MARX, 2010a, p. 62), e, assim, ter-se-ia uma consequência bastante importante: a política mesma, em sua “perfeição mesma”, e não por qualquer questão ligada a alguma “deformação” ou qualquer coisa do gênero, “e, consequentemente, tanto mais é incapaz de descobrir a fonte dos males sociais.” (MARX, 2010a, p. 62)

Sobre o terreno da política, e mais precisamente sobre o Estado ${ }^{13}$, diz ainda o autor alemão, de modo claro, que "todas as revoluções, assim, apenas aperfeiçoaram a máquina estatal, em vez de se livrar desse pesadelo sufocante” (MARX, 2011, p. 126). Se Marx é um revolucionário, percebese que a revolução que defende se coloca, também, contra o Estado. Ainda tendo em conta o tema, mas permeando o “terreno do Direito”, diz Karl Marx, novamente de modo direto, que "revoluções

\footnotetext{
${ }^{12} \mathrm{O}$ texto é de 1843, de modo que há autores, principalmente os althusserianos, que não o consideram como expressão do pensamento maduro de Marx (NAVES, 2014). De nossa posição, acreditamos que o "corte epistemológico" entre o “jovem Marx" e o "Marx maduro" não resiste à análise dos textos do próprio autor. Que há um desenvolvimento na obra marxiana, não há dúvida. No entanto, não acreditamos que isso se dê com um "corte", até mesmo porque tematizações "juvenis” do autor alemão aparecem explicitamente em seus textos "maduros” (SARTORI, 2012).

${ }^{13}$ Sobre a relação entre política, Estado e Direito na obra de Marx, cf. SARTORI, 2012.
} 
não são feitas por meio de leis” (MARX, 1987, p. 369). Nesse sentido, tanto nos primeiros textos de Marx (Glosas marginais), quanto nos últimos (Guerra civil na França) parece haver cerca continuidade no sentido da crítica ao Direito e à política (SARTORI, 2012).

Ou seja, mesmo que seja possível adquirir consciência acerca dos conflitos sociais que permeiam a sociedade civil-burguesa em meio às formas ideológicas conformadas no Estado e no Direito, de modo algum, caso se pretenda seguir o pensamento marxiano, elas podem trazer à tona, por si, qualquer modo de solução das questões sociais. No pensamento marxiano - se é verdade que elas podem ser, por vezes, essenciais ao processo de tomada de consciência acerca da conformação objetiva da realidade objetiva, bem como da necessidade de transformar a mesma - é igualmente verdadeiro que "os males sociais”, para Marx, só podem ser superados (aufgehoben) efetivamente quando a práxis política e jurídica, em meio às quais os homens "adquirem consciência” dos conflitos sociais, remete-os diretamente à transformação do solo social, em que se coloca a “totalidade das relações sociais de produção”.

Tanto o campo político como o “terreno do Direito” têm, segundo Marx, a conformação objetiva da sociedade civil-burguesa - em suas complexas relações - como um pressuposto que, “politicamente” e “juridicamente”, aparece como uma espécie de "segunda natureza”. Isso se dá na medida em que não se trata de simples epifenômenos, claro; há alternativas concretas colocadas, tanto ao campo político como ao campo jurídico, na própria realidade efetiva: não é indiferente, por exemplo, se há, ou não, o reconhecimento da jornada de 10 horas na Inglaterra do século XIX (MARX, 1988) ou se o Estado coloca-se a aprisionar os mendigos e os indigentes, ou se procura outra forma de lidar com a questão (MARX, 2010a). Nesse sentido, tanto o "reconhecimento" jurídico quanto a tomada de posição no campo estatal são campos considerados importantes por Karl Marx; no entanto, aquilo de basilar, de, por assim dizer, "estrutural” na conformação objetiva da sociedade civil-burguesa - o ser mesmo da realidade efetiva de uma época -, desenvolvida de acordo com o modo de produção da vida material, bem como pelo condicionamento do processo de vida intelectual, político e social, resta intocado caso não se remeta para além da politicidade (José Chasin, neste sentido, fala da existência de uma "metapolítica” em Marx; cf. CHASIN, 1999. Ou, caso se atenha ao "terreno do Direito", cf. SARTORI, 2015c).

E, aqui, é preciso enxergar a questão com bastante cuidado, novamente, para que se evitem as duas aproximações igualmente unilaterais das quais ressaltamos ser preciso se afastar. Este é um desafio para todos que buscam uma análise “marxista” (SARTORI, 2015b).

Caso se pretenda seguir os apontamentos do autor de O capital, a "perfeição” do “intelecto político” não estaria tanto na habilidade em compreender real e efetivamente a "base real” de que 
falou o pensador alemão; antes, em verdade, ela estaria, em certo modo (por assim dizer, “ilusório”), em lidar com a mesma, e esse modo traz a "unilateralidade” como marca, na medida mesma em que a peculiaridade da esfera política emerge à compreensão dos homens. A política, pois, como compreendida pelo autor de $O$ capital, não tem a radicalidade requerida para a transformação social real e efetiva ${ }^{14}$. Se ela quer se colocar de modo radical, por meio daquilo que Marx chamou de revolução social (MARX, 2010a, 2010b, 1997), ela precisa se colocar (praticamente) contra a própria especificidade da política, ligada às sociedades classistas e, portanto, passível de supressão:

Quando, no curso do desenvolvimento, desaparecerem os antagonismos de classes e toda a produção for concentrada nas mãos dos indivíduos associados, o poder público perderá seu caráter político. O poder político é o poder organizado de uma classe para a opressão de outra (MARX; ENGELS, 1998a, p. 59) ${ }^{15}$.

Se, por parte da política, o enfoque na vontade tem como correlato necessário a “cegueira” (ou ao menos a "miopia”) diante do modo pelo qual efetivamente se conforma a realidade efetiva da sociedade civil-burguesa, isto se dá, também, na medida em que “o poder organizado de uma classe para a opressão de outra”, a política mesma, vem a ser naturalizado de certo modo.

Com isso, se houvesse um ímpeto efetivamente “político” sendo buscado/retomado na sociedade capitalista, não se trataria, pois, de buscar a supressão (Aufhebung) daquilo que se coloca como indissolúvel da reprodução diuturna dos "males sociais”; antes, a política mesma aparece a Marx como inseparável da "base natural” dos últimos. As coisas aparecem em meio à politicidade como se se tratasse da busca de uma verdadeira e sincera "vontade política” e, assim, os "limites naturais” da vontade (vontade esta que sempre opera, por meio de esferas específicas da práxis social e em meio a determinado momento histórico em que alternativas não estão só na consciência dos homens, mas na própria realidade efetiva) não aparecem como tais em meio à politicidade mesma. Caso se pretenda seguir o pensamento marxiano, há de se admitir tratar-se, pois, de uma “forma ideológica” que, por si só, em sua "perfeição”, ou seja, em sua unilateralidade, segundo Marx, longe de trazer a possibilidade de supressão das raízes dos “males sociais”, tem estes últimos como pressuposto ineliminável, como algo que, na melhor das hipóteses, poderia ser remediado, ou eclipsado, o que é bastante distinto daquilo que o autor de $O$ capital pretende ao defender uma forma de sociabilidade que haveria quando “desaparecerem os antagonismos de classes”, sendo “toda a produção [...] concentrada nas mãos dos indivíduos associados” (MARX; ENGELS, 1998a, p. 59); em Marx, trata-se, portanto, justamente de suprimir o “poder político”, visto pelo autor

\footnotetext{
${ }^{14}$ Para o autor alemão, há de se romper com a casca reificada que se coloca, seja na política, seja no Direito, na medida em que "ser radical é segurar tudo pela raiz. Mas, para o homem, a raiz é o próprio homem.” (MARX, 2005, p. 53)

${ }^{15}$ Destacamos que a passagem se encontra no Manifesto Comunista, de tal modo que a crítica ao "caráter político” não é algo restrito a textos “de juventude” de Marx, como as Glosas Marginais.
} 
alemão como “o poder organizado de uma classe para a opressão de outra”. Tem-se uma crítica à própria política, pois.

E, neste sentido, não bastaria de modo algum buscar “aperfeiçoar” a “máquina estatal” ou a administração; a “perfeição” mesma destas ocorreria na medida em que a unilateralidade é pungente, escapando do controle consciente dos homens as suas relações sociais por meio das quais "fazem sua própria história”. Se formos seguir os apontamos de Marx, resta claro que se trataria de buscar nada menos que a superação (Aufhebung) real da sociedade capitalista - e é disso que se trata, afinal, para o autor alemão. A resolução dos "males sociais" somente poderia passar por uma transformação substantiva que, em verdade, não seria possível sem uma real e efetiva supressão do Estado e daquilo a ele subjacente.

Para o autor do O capital, não se coloca sequer a possibilidade de uma "suprassunção" (Aufhebung) ${ }^{16}$ das questões sociais no plano estatal e político, como ocorre em Hegel, por exemplo; não se trata, pois, de elevar a um patamar superior algo a ser substancialmente preservado, sendo, assim, distintas as concepções de Marx e de Hegel sobre a noção de Aufhebung (SARTORI, 2014a). Nesse sentido, a arquitetura jurídica e institucional passa longe de ser vista enquanto resolutiva por Marx. Ele destaca, de modo decidido, que não são as leis que levam uma revolução adiante, mas algo distinto delas; assim como não é a política (que se mantém como tal e não ultrapassa seus limites “políticos”) que poderia fazê-lo. No caso da política, a questão vem a ser central na medida em que, na melhor das hipóteses, ter-se-ia uma posição (Standpunkt) ${ }^{17}$ - comum nos círculos alemães neo-hegelianos - segundo a qual não se trataria tanto dos “interesses do proletário, mas os interesses do ser humano, do homem em geral, do homem que não pertence a nenhuma classe nem à realidade alguma e que só existe no céu brumoso da fantasia filosófica.” (MARX; ENGELS, 2008, p. 63)

Ou seja, tem-se justamente uma posição que, com apelo à política, viria a deixar de lado (enquanto algo a ser suprimido) justamente as determinações essenciais à posição específica dos homens reais em uma sociedade marcada pela antagonismo classista, como a sociedade capitalista. Nesse ponto específico, há um ponto importante a ser deixado mais claro, na medida em que Marx diz explicitamente que aqueles que compartilham de sua posição "se recusam a dissimular suas opiniões e seus fins” (MARX; ENGELS, 1998a, p. 69).

\footnotetext{
${ }^{16}$ Os dois primeiros sentidos do Aufhebung estão bastante presentes em Marx ao passo que o último uso do termo é, em nossa opinião, fortemente marcado pelo modo de se pensar a dialética que é característico de Hegel, principalmente daquele que se coloca na Ciência da lógica. Aqui, porém, não poderemos adentrar nos meandros deste debate. Para algumas diferenças decisivas entre Marx e Hegel, cf. SARTORI, 2014a.

${ }^{17}$ Para uma análise cuidadosa da noção de Standpunkt, cf. LOPES, 2010.
} 
Em meio à complexidade e contraditoriedade da sociedade civil-burguesa, justamente o modo pelo qual se colocaria a política dos trabalhadores poderia trazer consigo não só a possibilidade de o "poder público” perder "seu caráter político”; ter-se-ia que isto se dá na medida mesma em que qualquer ilusão acerca da possibilidade de se hipostasiar algo como uma "vontade política” seria extirpada, tendo-se uma posição abertamente contrária à possibilidade de haver uma “reconciliação” (Vörsonung) efetiva no seio da sociedade civil-burguesa e por meio do “intelecto político”. Marx, pois, coloca-se explicitamente de modo contrário à perpetuação da política e do Estado, destacando, inclusive, problemas congênitos na esfera política (relacionados a certa “unilateralidade”) ${ }^{18}$ ao mesmo tempo que, quer se queira, quer não, seria preciso passar pela mediação da esfera política para que, em uma sociedade como a capitalista, fosse possível uma transformação substantiva da sociedade, transformação esta que só ocorreria real e efetivamente quando “o poder público” perdesse “seu caráter político”.

Em Marx, pois, tem-se um posicionamento específico sobre a política, que a nega enquanto algo constitutivo da sociabilidade mesma do ser social, tratando-se de uma determinação “ontonegativa da politicidade” (CHASIN, 1999) ao mesmo tempo que, em meio às lutas políticas, é possível uma tomada de consciência acerca das raízes mesmas dos problemas sociais. Caso isso se desse, ter-se-ia o desenvolvimento de uma luta (também) política que solaparia suas próprias bases - a saber, o próprio antagonismo classista e a existência de um "poder organizado de uma classe para a opressão de outra”. Para Karl Marx, a política, por si, não traz consigo a possibilidade de resolução das questões pungentes da sociedade capitalista; ao mesmo tempo, porém, o contraditório desenvolvimento na mediação política na sociedade capitalista, sob a posição e busca pela hegemonia dos trabalhadores, poderia trazer consigo, junto com a supressão da sociedade civilburguesa, sua própria supressão.

\section{POLÍTICA E DIREITO COMO ESFERAS HETEROGÊNEAS, MAS RELACIONADAS}

Isso posto, pode-se passar ao campo do Direito, relacionando-o com a esfera política para que, então, seja possível tratar de sua especificidade na obra marxiana, especificidade esta que, já se adianta, passa pela também noção de “reconhecimento”. Antes de qualquer coisa, porém, é preciso

\footnotetext{
${ }^{18}$ Neste sentido, acreditamos que o tratamento dispensado pelo autor de $O$ capital em 1843, em textos como Sobre a questão judaica e as Glossas marginais, é plenamente compatível com aquele trazido no Manifesto Comunista, de 1848, bem como na Guerra civil na França, de 1871, todas estas, obras por nós citadas acima. Neste sentido, não podemos concordar com a posição de Márcio Naves, apoiada em Althusser, segundo a qual seria essencial traçar uma divisão clara entre um “jovem Marx” e um “Marx maduro”. Claro, há distinções na exposição do autor, bem como quando se tem em conta o amadurecimento intelectual marxiano. No entanto, o universo categorial de Karl Marx, mesmo que ainda não consolidado de modo pleno, já se encontra nos seus textos de 1843 (CHASIN, 2009; LUKÁCS, 2010).
} 
salientar algo que afirmou Engels sobre o "terreno do Direito" e sobre o Direito mesmo: ele “ocupa posição muito secundária nas pesquisas teóricas de Marx.” (ENGELS, 2012, p. 34)

Ou seja, se o autor de $O$ capital analisa a política ao tratar da luta de classes enquanto uma luta (também) política, ele não vai falar de uma “luta jurídica”, mas de uma luta pela diminuição da jornada de trabalho, por exemplo, que se encontra essencialmente no campo das relações sociais de produção, e do modo pelo qual essas relações se articulam real e efetivamente (por mais que venham a ter, também, um revestimento jurídico). Nesse sentido específico, parece ser possível dizer que as relações políticas, até certo ponto, trazem alguma tensão ao campo da efetividade (Wirklichkeit) social conformada na sociedade capitalista. Parece ser também possível dizer que, por vezes, esta última parece ser incompatível com a própria noção de cidadania; essas relações sempre têm suas raízes na "base real” mencionada por Marx (tal qual as relações jurídicas, diga-se de passagem), claro.

No entanto, se trazem consigo, como central, a noção de cidadania e a tentativa de tornar efetiva uma "universalidade irreal” (MARX, 2010b), em sua conformação objetiva mesma, a política representa uma tentativa frustrada de reconciliação das tensões existentes no solo da sociedade civil-burguesa (SARTORI, 2012); por outro lado, se seguirmos aquilo que aponta Marx, há no Direito, em verdade, uma relação muito menos tensa ante a conformação objetiva da sociedade capitalista. Ao relacionar a política com o Direito aponta-se que a "emancipação política” “encara a sociedade civil-burguesa, o mundo das necessidades, do trabalho, dos interesses privados, do Direito privado (Privatrechts), como o fundamento de sua subsistência” (MARX, 2010b, p. 53), na medida mesma em que o movimento pelo qual isso ocorre não é nada simples e, em Marx, é tratado em obras como 18 Brumário de Luís Bonaparte e Guerra Civil na França.

E, nesse ponto, já se apresentam aspectos importantes acerca da peculiaridade de cada esfera (jurídica e política) na obra marxiana.

Nesse sentido específico, se seguirmos os apontamentos marxianos será possível perceber que há um acoplamento muito maior do Direito em relação à sociedade civil-burguesa do que no caso da política: Marx parece mesmo destacar certa relação íntima da primeira com os "interesses privados" e com o "Direito privado", sendo que esses interesses têm sua sede justamente no particularismo da sociedade civil-burguesa; ou seja, se comparado com o ideal de cidadania, o Direito (privado) aparece em uma situação de desvantagem no que toca o grau de tensão em relação à sociedade civil-burguesa - a cidadania mesma o vê como algo contraposto, ao passo que, em verdade, também o toma, mesmo que indiretamente, como referência, ao ter como medida algo também a ele intimamente conectado - justamente o bourgeois. Por conseguinte, se pode haver 
certa tensão entre política, cidadania e a conformação objetiva das relações sociais de produção da sociedade capitalista (principalmente nos primeiros momentos da consolidação desta forma de sociabilidade, na Revolução Francesa, por exemplo), isso, ao menos de acordo com Marx, não se dá quando se tem em conta o Direito, o qual, na figura do Direito privado, está intimamente relacionado à “anatomia” mesma da sociedade civil-burguesa. As relações jurídicas, que se põem, claro, mediante a práxis permeada pelo Direito, nem sequer têm a pretensão, caso se parta do pensamento de Karl Marx, de se colocar como algo eivado de um espírito de “comunidade” (mesmo que “ilusório”), da participação cidadã.

E, neste ponto, é preciso analisar a questão trazendo à tona o modo pelo qual o Direito público, principalmente, a partir de certa centralidade que seria trazida com o constitucionalismo ao se tratar do campo jurídico, aproximar-se-ia muito mais do âmbito político, inclusive, na medida em que um de seus suportes estaria na noção de "vontade” soberana, a qual traria conjuntamente uma prevalência do "interesse público" ante o privado. Antes de analisar diretamente a questão, a partir daquilo que há de mais interessante nela - justamente certa defesa dos “direitos humanos” -, é necessário, porém, que se veja como Marx passa pela caracterização mais geral do Direito.

\section{O DIREITO E A HETEROGENEIDADE DESTE ANTE A POLÍTICA}

Uma passagem-chave para o tratamento das “questões jurídicas” a partir de Marx ${ }^{19}$ diz que: “o Direito nada mais é que o reconhecimento oficial do fato” (MARX, 2004, p. 84) (“Das Recht ist nur die offizielle Anerkennung der Tatsache”). Aí tem-se mesmo a possibilidade de questões sociopolíticas serem elevadas ao nível de “oficialidade”; caso partamos de Marx, será possível dizer, pois, que o Direito traz justamente isso: um grau de oficialidade. Na esfera jurídica, portanto, não há uma efetiva reconciliação (Vörsonung) das tensões colocadas no campo jurídico (questões, essencialmente, sociais), ou mesmo uma radicalização destas tensões - justamente o “reconhecimento oficial” tem consigo que, substancialmente, aquilo que se passa no plano políticosocial tomou determinado rumo.

A questão traz um duplo aspecto: ao mesmo tempo que esse reconhecimento é fruto de lutas sociais, como no caso da luta pela jornada de trabalho tratada em $O$ capital, este reconhecimento mesmo só se coloca como tal na medida em que a realidade efetiva já traz ela mesma seu desenvolvimento como algo “completo"; para que se faça uma aproximação com o pássaro de Minerva hegeliano, o Direito só chega ao entardecer, de tal feita que o reconhecimento pressupõe justamente que o processo constitutivo em que a objetividade (Gegenständlichkeit) se

\footnotetext{
${ }^{19}$ Cf. SARTORI, 2010. Para um desenvolvimento bastante interessante do tema, cf. LUKÁCS, 2013.
} 
coloca como tal já passou pelo processo de objetivação (Vergegenständlichung) e, somente assim, pode ser reconhecido. Partindo dos apontamentos marxianos, no Direito há somente reconhecimento post festum do modo pelo qual se desenvolvem relações sociais no campo sociopolítico. E, neste sentido, uma determinação importante da esfera jurídica se liga ao fato de o reconhecimento só poder se dar na esfera depois que a tensa relação entre o campo político e o socioeconômico tiver uma estabilidade relativa conformada real e efetivamente ${ }^{20}$.

Nesse sentido específico, aquilo que pode ser trazido pelo Direito ao campo da realidade efetiva da sociedade civil-burguesa é, ao mesmo tempo, "menos” e "mais" que o que é colocado no campo das lutas políticas. De um lado, tem-se somente o reconhecimento dos resultados das últimas; doutro lado, porém, sem este reconhecimento, as lutas políticas não chegam a uma institucionalização duradoura, o que, em determinadas circunstâncias, como na da luta pela diminuição da jornada de trabalho tratada por Marx em O capital, pode ser de enorme importância. O Direito, pois, não é mero epifenômeno, e a “oficialidade” trazida com ele, em Marx, pode ter um papel bastante importante; ao mesmo tempo, é preciso que se fique atento: se era possível uma política classista, por exemplo (a qual, buscaria a própria supressão das classes sociais, e, no limite, da própria política), o mesmo não se dá com o Direito, para o qual o "suicídio”, muito mais que no caso da política, é “antinatural” (MARX, 2010a). No modo como Marx trata dessas temáticas, a conformação do próprio Estado moderno tem como supostas estas questões ("políticas" e “jurídicas”), bem como o encadeamento delas na própria realidade efetiva, daí ser importante tratar de ambas, inclusive explicitando a heterogeneidade (e indissociabilidade) das esferas.

Ao tratar dessa relação, há de se ter em conta que no Estado há, politicamente, certa compreensão dos homens enquanto cidadãos, que, afinal, são inseparáveis do burguês (MARX, 2010b). Nisso há um aspecto essencial a ser destacado: de acordo com Marx, em meio à circulação de mercadorias (que tem consigo o fetichismo da mercadoria) há, no Direito, um "reconhecer-se (anerkennen) reciprocamente como proprietários privados” (MARX, 1988, p. 79). Logo depois de Marx ter tratado da reificação em $O$ capital, mostrando como na economia capitalista as relações sociais aparecem como se fossem relações entre coisas e as relações entre coisas como se fossem relações sociais (MARX, 1988), tem-se que o modo pelo qual os homens se colocam na esfera de circulação de mercadorias passa pelo “reconhecer-se reciprocamente como proprietários privados” e, nesse sentido, é preciso destacar: nada passa mais longe da concepção marxiana que enxergar a

\footnotetext{
${ }^{20}$ Como procuraremos mostrar à frente, a passagem da Miséria da filosofia é plenamente compatível com os apontamentos presentes em $\mathrm{O}$ capital, tendo-se também na obra magna de Marx a noção de reconhecimento como algo central. A questão, como pretendemos demonstrar, é que longe de o reconhecimento trazer à tona grandes virtudes do Direito, como querem autores importantes como Honneth, em Marx, não é isso que se dá.
} 
reificação como “esquecimento do reconhecimento” (HONNETH, 2012); antes, em meio à relação jurídica mesma, há o reconhecimento da reificação das relações sociais como uma espécie de “segunda natureza”, não se tratando tanto da elevação da "dialética da eticidade” hegeliana com a “suprassunção” dos interesses privados. Na relação jurídica, aquilo que é tomado como referência são os próprios interesses privados dos “proprietários privados”21.

Neste sentido, o reconhecimento presente no "terreno do Direito", se comparado com as tensões classistas que se apresentam mais diretamente no campo da práxis política, aproxima aquilo de "jurídico" justamente da sociedade civil-burguesa e faz com que, longe de poder gerar um tensionamento com o existente, o Direito o suponha de modo muito mais direto.

Ou seja, partindo do autor de O capital, pode-se dizer que há, no Direito, uma inversão característica que aparece de modo ainda mais forte que na política: se a política (que se mantém enquanto tal) malogra necessariamente em tentar reconciliar os antagonismos da sociedade civilburguesa ao passo que acredita poder dar conta da questão, no “terreno do Direito” parece que as vicissitudes e desigualdades da sociedade capitalista são suspensas (aufgehoben) quando se declara que todos são iguais perante a lei. Na medida mesma em que somente se “reconhece”, no Direito se acredita “criar” ou transformar relações sociais; desse modo, a impotência da esfera é, por assim dizer, simétrica às suas pretensões verbais. À medida que aquele que opera centralmente com o “jurídico” acredita ter em suas mãos algo essencial, isso lhe escapa cabalmente, e de modo ainda mais pungente do que se dá no campo político.

O modo pelo qual Marx e Engels trataram do "terreno do Direito" sempre foi de crítica (SARTORI, 2015c), relacionando-o não tanto à tensão cidadã com a sociedade civil-burguesa, mas à busca pela estabilidade institucional, que suporia a estrutura objetiva da sociedade capitalista. Se a aceitação desta última pelo discurso político não pôde se dar sem algumas tensões em pontos específicos, o mesmo não ocorre, em grau tão considerável, com o discurso jurídico, que, ao se voltar ao discurso constitucional (do Direito público, portanto), procura a estabilidade, a ser conseguida, não raro, com alianças espúrias, como narra Marx no 18 Brumário, por exemplo²2. Ou seja, Marx não tem sequer o "Direito público" como algo que, real e efetivamente, gera tensionamentos com o existente.

\footnotetext{
${ }^{21}$ Neste sentido, nota-se haver uma relação de complementariedade entre a passagem da Miséria da filosofia acima citada e esta importante passagem de $O$ capital.

${ }^{22}$ Como aponta Marx sobre a teoria ententista que aparecia no prelúdio das revoluções de 1848: "a teoria ententista, com a qual a burguesia prussiana, na pessoa de Camphausen e Hansemann, procurou justificar sua traição à revolução, consistia em que a Assembleia Nacional prussiana, permanecendo no terreno do Direito, devia se limitar à fundação de uma ordem constitucional por meio da conciliação com a Coroa.” (MARX, 2002, p. 243)
} 


\section{POLÍTICA, DIREITO, CLASSES SOCIAIS E IGUALDADE}

Em verdade, o modo pelo qual Marx equacionou a luta política passou muito mais pela “pré-história da sociedade humana” (MARX, 2009, p. 48), pela "história de todas as sociedades que existiram”, “a história da luta de classes” (MARX; ENGELS, 1998b, p. 9). Ou seja, não se tratou efetivamente de buscar qualquer forma de reconciliação efetiva por meio da política; em Sobre $a$ questão judaica, ele já mostrara como isso seria ilusório (SARTORI, 2012). Antes, com seu conteúdo social explícito, com a política - mas também para além dela (CHASIN, 1999) -, poderia haver certa forma de equacionamento da problemática política de modo que a essência antagônica das sociedades classistas viesse à tona. Ou seja, a esfera política, para o autor de O capital, passa longe de ser “solução”. Para que usemos a dicção de Lívia Cotrim (2010, p. 25), “longe de ser resolutiva, a politicidade é parte do problema a ser resolvido.”23 Porém, tem-se as tensões colocadas na esfera política como algo que pode ser levado adiante somente caso se ultrapasse a própria política (e busca a supressão da base real desta - a sociedade classista; em nosso caso, a sociedade civil-burguesa) e remeta à transformação substantiva das próprias relações sociais de produção, as quais, como mencionado acima, trazem as possibilidades objetivas sobre as quais se coloca a própria esfera jurídica. A “política” que defende Marx, pois, é algo que somente poderia ser chamado de "metapolítica” (CHASIN, 1999), buscando justamente a supressão daquilo que, em sua especificidade é “poder organizado de uma classe para a opressão de outra”.

Ou seja, por si, a política passa longe de oferecer um campo a ser perpetuado e a ser tomado como parâmetro para a práxis social; por mais que, no que toca à conformação objetiva da sociedade, nunca se possa, em hipótese alguma, "relegar o fato apenas ao jurídico 'terreno do Direito"” (ENGELS, 2012, p. 20), isso não faz com que Marx e Engels estabeleçam um elogio à política. Antes, tem-se, a rigor, o oposto. O campo jurídico, pois, em suas próprias determinações objetivas, tem menos potencialidades se comparado com o político; porém, como restou claro acima, o essencial não está propriamente em nenhum dos dois campos; segundo Marx, está na transformação da "totalidade das relações sociais de produção", que foi mencionada acima a partir do autor de $O$ capital e que tem grande relevo no tratamento marxiano dos problemas de sua época.

\footnotetext{
${ }^{23}$ A continuação da passagem citada traz aspectos importantes, que dão destaque à relação estabelecida entre a esfera da política e a divisão social do trabalho, bem como de sua relação na oposição entre indivíduo e gênero (temática tratada em Sobre a questão judaica, mas também na Ideologia alemã e nos Grundrisse: “a emancipação política funda-se na e expressa a cisão objetiva, decorrente de relações de produção assentadas na divisão social do trabalho e na propriedade privada, de cada indivíduo em homem (burguês) de vida privada e cidadão de vida pública, o primeiro despojado de sua condição genérica social e assim naturalizado, o segundo defraudado de suas qualidades individuais; esse divórcio entre individuo e gênero, essa cesura entre indivíduos autoprodutores e as forças sociais, genéricas, por eles produzidas, transformam-nas em forças políticas a eles contrapostas.” (COTRIM, 2010, p. 25)
} 
Ao passo que, por meio da explicitação da diferença e da contraposição, a política poderia, em algumas circunstâncias, e amparada pela luta de classes (CHASIN, 1999), levar para além de si mesma, o mesmo não se dá, em verdade, no "terreno do Direito". Este, segundo a Crítica ao programa de Gotha, coloca-se objetiva e efetivamente eclipsando as diferentes medidas que permeiam a posição das distintas classes sociais. Veja-se a passagem de Marx sobre o tema:

O Direito, por sua natureza, só pode consistir na aplicação de um padrão igual de medida; mas os indivíduos desiguais (e eles não seriam indivíduos diferentes se não fossem desiguais) só podem ser medidos segundo um padrão igual de medida quando observados do mesmo ponto de vista [Gesichtspunkt], quando tomados apenas por um aspecto [...], todos os outros aspectos são desconsiderados. (MARX, 2012, p. 31)

Se podem existir “relações jurídicas” que são permeadas por um "tratamento desigual aos desiguais” - e isto teria sido essencial para a história do século XX - isso não se dá tanto, se seguirmos Marx, devido a alguma mudança na conformação objetiva do Direito. Antes, ter-se-ia isso justamente na medida em que tensões políticas (que podem trazer e explicitar a diferença específica entre as classes sociais à tona) são transplantadas para o "terreno do Direito", sendo “reconhecidas” oficialmente. Se for possível seguir aquilo que aponta Marx, “por sua natureza”, o campo jurídico, por si, não é capaz de considerar particularidade que permeia as próprias individualidades (e, assim, em verdade, também o modo pelo qual as determinações classistas permeiam a posição de cada uma dessas). Com o Direito, a consideração da igualdade, por exemplo, “somente pode consistir na aplicação de um igual padrão de medida”, e nada mais; quer se queira, quer não, Marx é explícito quanto a isso. Engels apontou a "emancipação dos entraves feudais e a implantação da igualdade jurídica, pela abolição das desigualdades do feudalismo” (ENGELS, 1990, p. 89) e, seguindo Marx, pode-se dizer que a universalidade do Direito coloca-se justamente com a “abolição” mencionada, tendo-se o triunfo “do Direito burguês sobre os privilégios medievais” (MARX, 2010c, p. 322).

A aplicação de um "igual padrão de medida" coloca-se justamente sobre esta base, de modo que a concepção de igualdade colocada por Marx no "terreno do Direito" passa longe de uma real "igualdade econômica e social”; seguindo os apontamentos de Karl Marx, se a igualdade pode passar a ser algo a ser almejado pelos trabalhadores, não se trataria tanto de algo que permeia alguma forma de efetivação daquilo postulado na esfera jurídica; antes, ter-se-ia algo que busca superar (aufheben) a igualdade jurídica, relacionada por Marx na Crítica ao programa de Gotha ao “estreito horizonte jurídico burguês” (MARX, 2012, p. 33), criticado decididamente por Engels²4.

\footnotetext{
${ }^{24}$ Engels traz a questão apontando que “a burguesia francesa, sobretudo depois da Grande Revolução, passou a considerar em primeiro plano a igualdade burguesa, o proletariado francês coloca, passo a passo, as suas próprias
} 
Ou seja, não haveria como o Direito, em si, em sua própria especificidade, considerar distintas formas pelas quais se apresentam "pontos de vista” distintos, marcados por interesses classistas distintos - ele, de modo algum, traz qualquer possibilidade de reconciliação com as tensões advindas da estrutura objetiva da sociedade civil-burguesa em sua conformação objetiva enquanto esfera do ser social, e ainda traz certo fechamento ante os horizontes da própria luta de classes que, em Marx, para se colocar de modo efetivamente proveitoso, trazem uma posição daqueles que "se recusam a dissimular suas opiniões e seus fins"; segundo o autor de $O$ capital, no Direito, os indivíduos somente poderiam ser “medidos segundo um padrão igual na medida” (o que já leva à impossibilidade de distintas posições concretas, que trazem consigo "medidas” distintas, no "terreno do Direito”), havendo tal “igual padrão” somente “quando observados do mesmo ponto de vista”, tendo-se "todos os outros aspetos”, ao final, “desconsiderados”.

Ou seja, justamente na medida em que se tem a "aplicação" de um "igual padrão de medida”, os aspectos decisivos no que diz respeito à conformação objetiva da base real de uma dada sociedade são deixados intocados, e a universalidade do "terreno do Direito" tem como contraponto necessário e complementar o particularismo da sociedade civil-burguesa (SARTORI, 2012); justamente na medida em que se coloca o “igual padrão de medida”, tem-se uma forma de igualdade que só é efetiva como tal ao "reconhecer” a desigualdade social real e efetiva na sociedade capitalista. O "reconhecimento" que se consegue por meio do Direito tem consigo, pois, ao fim, não tanto o ápice de um processo ascensional e progressivo de lutas sociais (embora isso ocorra em certa medida, principalmente na supressão dos privilégios medievais), mas, na sociedade capitalista colocada sobre seus próprios pés, o “reconhecimento” dos “males sociais” como algo reificado, como uma espécie de segunda natureza. Ou seja, o reconhecimento não se coloca tanto como algo contraposto à fetichização e reificação das relações sociais, como quer Honneth (2012); antes, trata-se justamente de tomar como base a fetichização e a reificação mesmas em um "igual padrão de medida”. Trata-se, portanto, de, com o Direito, reconhecer relações eivadas pela reificação.

Não só é necessário dizer que particularidade da política e do Direito são, de certo modo, como se nota acima, traçadas por Marx: isto se dá na medida em que as possibilidades presentes no campo jurídico são consideravelmente menores. Este somente “reconhece”, “oficialmente”, aquilo que é colocado - mediante lutas sociais - noutros “terrenos”, como aquele da práxis política. E, percebe-se: se, na política, seria possível uma espécie de “metapolítica” tendo em conta uma 
revolução social (MARX, 2010a), o mesmo não se dá no Direito que, na melhor das hipóteses, remeteria à esfera, já bastante problematizada por Marx, da política e do Estado, sendo as lutas neste campo marcadas por “formas ilusórias” (MARX; ENGELS, 2007), as quais estariam ultrapassadas (aufgehoben) prática, real e efetivamente nas lutas sociais dos trabalhadores.

\section{OS DIREITOS DO HOMEM E O PAPEL DO RECONHECIMENTO NO TERRENO DO DIREITO}

Nossa análise padeceria de um vício incurável se não procurasse também tratar daqueles pontos que, no "terreno do Direito mesmo", parecem ter maior potencial nas lutas sociais. Neste último momento do texto, pois, mesmo que rapidamente, analisaremos aquele aspecto da esfera jurídica que mais traz a possibilidade de se extrapolar o “estreito horizonte jurídico burguês”.

Tendo em conta a tematização dos “direitos do homem”, o autor de $O$ capital tece alguns comentários importantes para se compreender o modo como entende a questão do Direito. Neste campo, já em Sobre a questão judaica, Marx mostra como seria impossível dissociar o particularismo da sociedade civil-burguesa do ímpeto cidadão, que aparece nos “direitos do homem” (SARTORI, 2012), apontando como estes se ligam bastante a uma situação em que o indivíduo aparece de modo "genérico" e "universal”, somente tendo "sido privado da sua vida individual real e preenchido com uma universalidade irreal.” (MARX, 2010a, p. 40) E, nesse sentido, percebe-se a maior proximidade desses direitos quanto ao campo da política se comparados ao modo como se tem o "Direito privado", este último com um grau de acoplamento bastante grande com a sociedade civil-burguesa. Ou seja, justamente nesse campo - dos “direitos do homem” - seria possível trazer um tensionamento maior com o existente.

No entanto, não se pode deixar de apontar que, em $O$ capital, o autor é bastante direto acerca do modo pelo qual esses direitos relacionam-se com as relações sociais de produção. Diz o autor que "a esfera da circulação ou do intercâmbio de mercadorias, dentro de cujos limites se movimentam compra e venda de força de trabalho, era de fato um verdadeiro éden dos direitos naturais do homem.” (MARX, 1987, p. 144) Ou seja, longe de ser possível se contrapor à “esfera da circulação ou do intercâmbio de mercadorias" por meio de uma valorização dos “direitos naturais do homem”, tem-se o modo pelo qual aquilo que dá a tônica e a base real para a manifestação desses direitos é “a venda da força de trabalho”, cujo fundamento está na relação-capital, que deveria ser superada, segundo $\operatorname{Marx}^{25}$.

\footnotetext{
${ }^{25}$ Diz o autor de $O$ capital que "a relação-capital pressupõe a separação entre os trabalhadores e a propriedade das condições de realização do trabalho. Tão logo a produção capitalista se apoie sob os próprios pés, não apenas conserva
} 
Aqui, pois, tem-se, em um maior grau de concretude, justamente o que foi trazido em Sobre a questão judaica; a saber, a impossibilidade de se contrapor real e praticamente o bourgeois ao citoyen, tendo-se, sob este aspecto, continuidade entre “jovem Marx” e "Marx maduro".

A questão, na obra do autor de $O$ capital, aparece mediante a tematização do Direito mesmo. E, assim, o "terreno do Direito”, em sua melhor expressão, tem consigo tanto a busca de algo que pode ser visto como uma “comunidade ilusória”, uma “universalidade irreal”, quanto certa impossibilidade de ser dissociado da "esfera da circulação ou do intercâmbio de mercadorias"; e, desse modo, com maior concretude - e já trazendo à tona a efetiva especificidade da esfera jurídica -, a relação entre o burguês e o cidadão, que foi central à Sobre a questão judaica, é desenvolvida por Marx em O capital, em que a “totalidade das relações de produção”, “a estrutura econômica da sociedade”, é analisada com rigor e em que se mostra a conformação dos “direitos do homem” e da circulação de mercadorias subsumida ao domínio do capital enquanto determinações reflexivas (Reflexionsbestimmungen), ligadas em uma interdependência incindível ${ }^{26}$.

No que, tendo isto em mente, ao tratar desta esfera - “a esfera da circulação ou do intercâmbio de mercadorias” -, complementa Marx com algo essencial à nossa análise:

O que aqui reina é unicamente Liberdade, Igualdade, Propriedade e Bentham. Liberdade!
Pois comprador e vendedor de uma mercadoria, por exemplo, da força de trabalho, são
determinados apenas por sua livre vontade. Contratam como pessoas livres, juridicamente
iguais. O contrato é o resultado final, no qual suas vontades se dão uma expressão jurídica
em comum. Igualdade! Pois eles se relacionam um com o outro apenas como possuidores
de mercadorias e trocam equivalente por equivalente. Propriedade! Pois cada um dispõe
apenas sobre o seu. Bentham! Pois cada um dos dois só cuida de si mesmo. O único poder
que os junta e leva a um relacionamento é o proveito próprio, a vantagem particular, os seus
interesses privados. (MARX, 1987, p. 144)

Segundo o autor, não se poderia pois contrapor o individualismo possessivo da sociedade civil-burguesa aos direitos do homem; tratar-se-ia de determinações reflexivas, de tal modo que mesmo um autor como Bentham (que Marx reputa como alguém de teoria cínica e execrável) é visto por Marx como alguém que deve ser visto em conjunto com a "liberdade” e com a “igualdade”, defendido por aqueles que acreditam no potencial emancipador dos direitos humanos ${ }^{27}$.

tal separação, mas a reproduz em escala sempre crescente. Portanto, o processo que cria a relação-capital não pode ser outra coisa que não o processo de separação entre o trabalhador e a propriedade das suas condições de trabalho, um processo que por um lado transforma os meios sociais de subsistência e de produção em capital, por outro, os produtores imediatos em operários assalariados.” (MARX, 1987, p. 252)

${ }^{26}$ Aqui não podemos tratar da questão relativa à oposição entre a obra "juvenil” de Marx e sua obra "madura”. Pelo nosso posicionamento destacado até agora, porém, resta nossa posição contrária à tese althusseriana acerca do "corte epistemológico”, tendo-se, por conseguinte, nossa oposição às conclusões de Márcio Naves (2014) sobre o assunto.

${ }^{27}$ Vale destacar que Marx traz à tona ao falar dos direitos humanos alguém como Bentham. Este último aceita, segundo o autor de $O$ capital, de modo acrítico a economia capitalista. Não nos parece que seja acidental que ao remeter ao terreno do Direito nesta passagem, Marx não traga um autor revolucionário como Rousseau. Isto se dá porque, na esfera de circulação de mercadorias, há um acoplamento bastante claro entre estes direitos e as vicissitudes da sociedade 
Ou seja, mesmo ao se ter o “terreno do Direito” em sua melhor expressão, o autor de O capital deixa claro que outro lado necessário à “universalidade irreal” e à “comunidade ilusória” trazidas à tona nesses direitos é o “reconhecimento” - inclusive, “oficial” - da “vantagem particular, os seus interesses privados”. Mesmo que de modo mais mediado, pois trata-se sempre com o Direito do “reconhecimento oficial do fato”. O Direito não se limita a essa função, pois está, por vezes (como no caso dos direitos do homem), permeado por aspectos políticos de modo muito mais íntimo que no Direito privado. No entanto, é preciso que se perceba: isso não se dá tanto por causa dos aspectos “jurídicos” desses direitos, mas devido a seus aspectos “políticos”.

Ocorre, porém, que a questão, segundo o autor de $O$ capital, nunca pode ser separada da “outra face” da cidadania e da política: o movimento real da sociedade civil-burguesa expresso também na "esfera da circulação ou do intercâmbio de mercadorias”. Em verdade, nesse sentido se reconhece, em relação aos direitos do homem, na medida mesma em que há certa valorização da “dignidade do homem”, relacionada à autonomia de sua vontade, justamente a "livre vontade” que reina na esfera de circulação de mercadorias e se coloca na figura do contrato, que pressupõe a relação-capital, e que traz consigo o locus da compra e venda da força de trabalho.

Assim, ao contrário do que se tem no campo da política, em que o antagonismo classista aparece como essencial ao se explicitar estas determinações no processo de luta de classes (seja na medida em que ele é explicitado, seja na medida em que se busca uma espécie de reconciliação com este), no “terreno do Direito” há um eclipse desse aspecto, também com os direitos humanos. Esse aspecto vem a ser visto somente em sua manifestação fenomênica trazida à tona com a noção de igualdade jurídica. E isso certamente se relaciona com o "padrão igual de medida”, que, “juridicamente”, é aplicado a indivíduos que pertencem a classes sociais distintas e cujas posições reais e efetivas na sociedade fazem com que haja desigualdades substanciais. Assim, segundo os textos marxianos, com o Direito tem-se justamente o reconhecimento dessas desigualdades substanciais, e não algo que se oponha real e efetivamente a elas ${ }^{28}$.

Ou seja, ao passo que a política é o âmbito em que as desigualdades são constitutivas do confronto e em que podem ser colocadas explicitamente na luta de classes, o Direito é o campo em

capitalista, tendo-se o bourgeois em foco. Caso se buscasse a “outra face” destes direitos - seu aspecto ligado à cidadania - seria possível a Marx remeter a autores para quem o citoyen é central, como Rousseau. Pelo que colocamos aqui, ao se ter em conta a obra marxiana, um suposto potencial emancipador dos direitos humanos seria, em verdade, bastante ilusório, já que, em verdade, as “duas faces” destes direitos seriam inseparáveis. Isto, no entanto, não se opõe à maior proximidade destes direitos com o campo político se comparado à esfera do Direito privado.

${ }^{28}$ No começo do texto, trouxemos a importância de se considerar que também por meio do Direito, os homens tomam consciência dos conflitos sociais. Isto não é retirado de campo aqui. Tanto na política quanto no Direito, isto pode se dar. No entanto, pelo que destacamos aqui, segundo Marx, as dificuldades para que isso se dê na esfera jurídica parecem ser maiores já que no terreno do Direito parece haver certo ocultamento das desigualdades que marcam a sociedade civilburguesa, mesmo no caso dos direitos humanos. 
que essas desigualdades afloram com muito mais dificuldade, devendo-se, nas "lutas por direitos”, passar justamente pela mediação da política antes que se possa chegar a qualquer "reconhecimento oficial”. Mesmo a relação entre Direito e luta de classes é muito mais mediada que aquela que ocorre no campo da política, um terreno que, mais facilmente, traz à tona o antagonismo classista. Este último só aparece nas lutas sociais que procuram reconhecimento no campo jurídico na medida em que aquilo mesmo a ser reconhecido (determinado resultado de lutas sociais específicas) se coloca para além da particularidade da esfera jurídica (ligada à aplicação de um “igual padrão de medida”) e adentra o campo político, que, por seu turno, remete ao econômico-social. Para que se explicite a questão: se lutas sociais trazem consigo o reconhecimento por parte do campo jurídico, isso se dá porque se trata essencialmente de uma luta política que, no limite, poderia procurar a transformação social. Ou seja, tem-se algo que justamente poderia, segundo Marx, suprimir o reconhecimento dos homens enquanto proprietários privados, o que se dá com o Direito.

Pode-se mesmo apontar que a questão do Direito fica mais intimamente ligada a um sentido que fortalece as vicissitudes da sociedade capitalista, em vez de se opor a elas, quando se tem em conta a forma de individualismo e de personalidade ${ }^{29}$ que advém desta conformação objetiva de que Marx trata. Tem-se certamente, neste campo, certo reconhecimento; no entanto, isso se dá justamente na medida em que os homens veem a si mesmos como pessoas ao reificar as relações sociais de produção colocadas sobre a sociedade capitalista; neste reconhecimento, "eles devem, portanto, reconhecer-se reciprocamente como proprietários privados.”

A própria conformação da individualidade do homem da sociedade civil-burguesa traz uma relação estranhada entre indivíduo e gênero (justamente o tema tratado em Sobre a questão judaica), tendo-se, de um lado, o reconhecimento se colocando na relação jurídica quando se conforma o individualismo atomista, e, doutro, a "universalidade irreal”. Em meio às relações sociais de produção capitalistas tem-se este “éden dos direitos naturais do homem”, na medida em que os homens reconhecem a si mesmos como "pessoas" somente quando "o único poder que os junta e leva a um relacionamento é o proveito próprio, a vantagem particular, os seus interesses privados.” Vê-se, pois, de modo mais concreto, em O capital, a retomada de aspectos essenciais tanto a Sobre $a$ questão judaica, quanto à Miséria da Filosofia, textos que, não raro, são deixados de lado ao se tratar do Direito em Marx.

Há de se destacar, portanto, que, quer se queira quer não, a estrutura objetiva subjacente aos direitos do homem, em Marx, está naquilo mesmo que eles, por vezes, aparentam negar de

\footnotetext{
${ }^{29}$ Marx diz sobre a relação entre mercadorias e os homens na esfera da circulação mercantil que "para que essas coisas se refiram umas às outras como mercadorias, é necessário que os seus guardiões se relacionem entre si como pessoas (Personen), cuja vontade reside nessas coisas” (MARX, 1988, p. 79).
} 
modo decidido. Neste campo, justamente o aspecto central para se tratar das questões decisivas aos rumos (para Marx, à supressão) da sociedade civil-burguesa é aquele que aparece como algo inquestionado e inquestionável ao "terreno do Direito"; a saber, o trabalho assalariado e a separação entre produtores e meios de produção que o primeiro tem como requisito. De acordo com o autor de O capital, falar de direitos do homem implicaria, em verdade, falar da exploração da força de trabalho enquanto um “dado”, ao fim, ineliminável. Neste sentido específico, não haveria como separar a "igualdade” dos direitos humanos de "Bentham”; ou seja, de uma forma de individualismo crasso e possessivo, de algo que o autor alemão considerava execrável e nem sequer passível de respeito, tendo em mente o passado democrático da burguesia que aparece, de modo mediado, em Smith e Ricardo, por exemplo, mas também em autores da filosofia como Kant e Hegel.

Assim, segundo Marx, o real “reconhecimento” que se dá no “terreno do Direito”, em um sentido, pressupõe já a reconciliação (nunca passível de completude) da esfera política com a sociedade civil-burguesa e, assim, o "reconhecimento oficial do fato" só pode se dar tendo em conta a reificação desta sociedade específica, que, com a mediação jurídica, é tomada enquanto algo contra o qual não se pode lutar realmente; noutro sentido, porém, a questão fica ainda menos favorável à defesa marxista da bandeira dos direitos humanos enquanto algo estratégico: o “reconhecimento" que se tem no "terreno do Direito” aparece na medida em que o próprio verniz da noção de cidadania tende a desaparecer progressivamente e os homens passam a se relacionar de modo bastante menos mediado com as mercadorias, de tal feita que eles se apresentam como indivíduos proprietários “cuja vontade reside nessas coisas, de tal modo que um, somente de acordo com a vontade do outro, portanto, apenas mediante um ato de vontade comum a ambos, se aproprie da mercadoria alheia enquanto aliena [veräußert] a própria” (MARX, 1988, p. 79) Tem-se indivíduos proprietários que, como não poderia deixar de ser, “devem, portanto, reconhecer-se (anerkennen) reciprocamente como proprietários privados”, proprietários estes que, na medida mesma em que aparecem como alguém que pode exercer seu poder sobre as “coisas” (Dinge) curvam-se ao movimento das mercadorias que é trazido com a reprodução do capital. Em Marx, o próprio modo de operar do Direito traz, pois, consigo, não tanto uma tensão com o movimento específico da “anatomia” da sociedade civil-burguesa, mas a aceitação e a submissão à mesma.

Talvez se possa mesmo dizer que a esfera jurídica, nesse sentido, é ligada de modo pungente ao estranhamento (Entfremdung), tema este tratado nos Manuscritos econômicofilosóficos justamente em relação com a categoria de Veräusserung, relacionada ao verausert, citado na passagem de $O$ capital. E, também neste ponto, pode-se problematizar a aceitação do "corte epistemológico” supostamente existente entre “jovem Marx” e “Marx maduro”. 
Marx aponta explicitamente que “o Direito nunca pode ultrapassar a forma econômica e o desenvolvimento cultural, por ela condicionado, da sociedade” (MARX, 2012, p. 31). E isto se dá até mesmo porque, ao se ter em conta a relação jurídica colocada no “terreno do Direito”, que é, em verdade, aquele da sociedade civil-burguesa, “o conteúdo dessa relação jurídica ou de vontade é dado por meio da relação econômica mesma (ökonomische Verhältnis selbst).” (MARX, 1988, p. 79) A ligação entre estas questões e a noção de “reconhecimento” aparece claramente em Marx:

Demonstrou-se como o reconhecimento [Anerkennung] dos direitos humanos [Menscherechte] por parte do Estado moderno tem o mesmo sentido que o reconhecimento da escravatura pelo Estado antigo. Com efeito, assim como o Estado antigo tinha como fundamento natural [Naturbasis] a escravidão, o Estado moderno tem como base natural a sociedade [civil-]burguesa [bürgerliche Gesellschaft] e o homem da sociedade [civil]burguesa, quer dizer, o homem independente, entrelaçado com o homem apenas pelo vínculo do interesse privado [Privatinteresses] e da necessidade natural inconsciente [bewußtlosen Naturnotwendigkeit], o escravo do trabalho lucrativo e da necessidade egoísta [eigennützigen Bedürfnisses], tanto da própria quanto da alheia. O Estado moderno reconhece [anerkannt] essa sua base natural [Naturbasis], enquanto tal, nos direitos gerais do homem [allgemeinen Menschenrechten]. Mas não os criou. Sendo como é, o produto da sociedade burguesa, impulsionada por seu próprio desenvolvimento [Entwirckelung] até mais além dos velhos vínculos políticos, ele mesmo reconhece, por sua vez, seu próprio local de nascimento e sua própria base mediante a proclamação dos direitos humanos. (MARX; ENGELS, 2003, p. 132)

A relação entre reconhecimento, Direito e a conformação objetiva da sociedade capitalista resta clara na passagem, sendo explícita a prioridade ontológica das relações socioeconômicas sobre a forma jurídica ${ }^{30}$ (SARTORI, 2010; LUKÁCS, 2013). As diferentes formas ideológicas, que só se conformam como tais ao realizar uma função na efetividade do ser social (VAISMAN, 2010), trazem consigo, na passagem, o “fato”, reconhecido no "terreno do Direito”, segundo o qual "o Estado moderno tem como base natural a sociedade civil-burguesa”; a noção de reconhecimento aparece em Marx, pois, intimamente ligada à prioridade ontológica da própria objetividade (Gegenständlichkeit) sobre as distintas formas ideológicas, como a jurídica. Mesmo ao se ter em conta algo como os direitos humanos isso se dá. Se formos seguir Marx, por mais que essas ideias sejam aquelas que - no campo jurídico - mais se aproximam de um tensionamento com o existente, ao final só podem reconhecer a sociedade existente como sua "base natural”.

\footnotetext{
${ }^{30}$ Aqui é preciso ressaltar que não remetemos à problematização pachukaniana sobre a forma jurídica. Nas passagens acima, Marx fala da "forma do contrato" que, em verdade, teria como subjacentes as "relações econômicas mesmas". Neste sentido que trazemos à tona a expressão. Este sentido pode ser esclarecido pela seguinte passagem de Engels: “o Estado, depois de adquirir poder independente frente a sociedade, cria, rapidamente, uma nova ideologia. Nos políticos profissionais, nos teóricos do Direito público e nos juristas que cultivam o Direito privado, desaparece por completo a consciência da relação com os fatos econômicos. Como, em cada caso concreto, os fatos econômicos precisam tomar forma de motivos jurídicos para serem sancionados na forma de lei, e como, para isso, é necessário, também, logicamente, considerar todo o sistema jurídico, pretende-se que a forma jurídica seja tudo, e o conteúdo econômico, nada. O Direito público e o Direito privado são considerados dois campos independentes, com desenvolvimento histórico próprio; esses campos não só permitem, mas exigem, por si mesmos, uma construção sistemática, sendo necessária, consequentemente, a eliminação de todas as contradições internas.” (ENGELS, 1962, p. 129)
} 
Para que se deixe claro o modo pelo qual as próprias determinações do Direito o levam a uma posição incapaz de romper com sua "base natural”, a analogia de Marx é mesmo dura: “o reconhecimento dos direitos humanos por parte do Estado moderno tem o mesmo sentido que o reconhecimento da escravatura pelo Estado antigo” (MARX; ENGELS, 2003, p. 132). A exposição do autor de $O$ capital, quando se chega a esse ponto, não deixa dúvidas: mesmo quanto à manifestação mais interessante e progressista do Direito, é necessária uma crítica decidida ${ }^{31}$. Se Marx pôde se apoiar em uma concepção de política (como “metapolítica”) em que esta ultrapassasse seus horizontes, podendo, no limite, suprimir-se, o mesmo não acontece no "terreno do Direito". Neste, o reconhecimento se apresenta na medida mesma em que aquilo que se deve procurar suprimir real e efetivamente é tomado como uma "base natural”, um "fundamento" sobre o qual o verniz "público" desses direitos reveste o "interesse privado" e a "necessidade natural inconsciente", esta última tomada como uma "segunda natureza” na medida mesma em que se conforma enquanto uma potência estranhada e estranhante.

\section{POR UMA CRÍTICA AO DIREITO E AO MODO DE PRODUÇÃO CAPITALISTA}

Segundo Marx, os “direitos gerais do homem”, pois, na medida mesma em que se aproximam de uma "forma ilusória da comunidade (Allgemeine illusorische Form der Gemeinschaftlichkeit)” (MARX; ENGELS, 2007, p. 37) característica da política, trazem consigo o reconhecimento do "interesse privado" que permeia a sociedade civil-burguesa. Assim, por mais que seja também nas "lutas no interior do Estado" que "são travadas as lutas reais (wirkliche Kämpfe) entre as diferentes classes” (MARX; ENGELS, 2007, p. 37), essas são tomadas por Marx como “formas ilusórias” (MARX; ENGELS, 2007, p. 37), contra as quais seria preciso uma posição decidida, na medida em que não bastam, por exemplo, leis que busquem suprimir a "desigualdade social e política”; trata-se da supressão das próprias classes sociais, de tal feita que, ao comentar o programa de Gotha, Engels diz, não sem alguma ironia, algo decisivo: “'eliminação [Beseitung] de toda desigualdade social e política', em vez de 'superação [Aufhebung] de toda distinção de classe', é também uma expressão muito duvidosa.” (ENGELS, 2012, p. 55) (,Beseitung aller sozialen und politischen Ungleicheit‘ ist auch eine sehr bedenkliche Phrase statt, Aufhebung aller Klassenuntershiede‘.)

\footnotetext{
${ }^{31}$ Neste ponto cabe uma ressalva, que, a rigor, seria desnecessária, mas vale a pena fazer. Marx, como alguém que viveu no século XIX, não viu o desenvolvimento do constitucionalismo posterior à república de Weimar, nem o modo pelo qual os direitos humanos se relacionaram com certas conquistas trabalhistas. Nosso texto não pretende tratar da questão, dado que se trata de um artigo sobre Marx, e não sobre os direitos humanos como tais. Para uma crítica ao contexto em que os direitos humanos se desenvolvem abrigando conquistas trabalhistas, cf. LUKÁCS, 1959; SARTORI, $2015 d$.
} 
Neste sentido específico, aos olhos de Marx e Engels, mesmo aquilo que é colocado pelos juristas como fundamento do Direito público, os próprios direitos humanos, ainda que vistos em um tom bastante crítico, em que se busca a "eliminação" de toda distinção de classe (algo absolutamente incomum, diga-se de passagem), ou seja, a igualdade mais radical possível, tendo-se a política como ponto de referência, passa longe de ser suficiente para uma posição efetivamente crítica. O Direito só poderia ser, nesse sentido, “reconhecimento oficial do fato”, possuindo muito menos possibilidades que a esfera política também ao se ter em conta aquilo que há de mais radical na "luta por direitos”. Tendo tudo isto em conta, é agora plenamente possível compreender por que, segundo Marx, mesmo um Direito que buscasse a distribuição efetivamente igualitária da riqueza social traria consigo marcas indeléveis: "segundo seu conteúdo, portanto, ele é, como todo direito, um direito da desigualdade.” (MARX, 2012, p. 32)

Percebe-se, pois, ser essencial para a compreensão marxiana traçar a diferença específica existente entre as diversas esferas de determinada sociabilidade. Nesse sentido, percebeu-se que o modo como o Direito e a política são tratados na obra do autor são bastante distintos, tendo-se a noção de "reconhecimento" como algo central no campo jurídico na medida mesma em que esta última não se coloca de modo essencialmente "crítico", mas quando se admite justamente impotência do Direito diante dos imperativos colocados na sociedade civil-burguesa. Trata-se, em verdade, de imperativos permeados justamente pela reificação das relações sociais, reificação esta que autores como Honneth, por exemplo, acreditam que é possível ser tratada como "esquecimento do reconhecimento".

Esse último ponto pode ser ainda bastante desenvolvido; no entanto, desde já é preciso que fique claro que, ao menos nesse ponto, tem-se uma antítese direta entre Marx e um importante autor que se pretende herdeiro justamente de uma tradição a qual não pôde se desenvolver sem a influência decisiva do autor de $O$ capital. Se teóricos contemporâneos que pretendem dar um talhe crítico às suas teorias - não importa se correta ou erroneamente, este não é o ponto deste texto - têm por central tanto a noção de reconhecimento (normalmente encadeada à luta por direitos) quanto uma reconceituação da política, isto se dá como que em uma antítese direta àquilo desenvolvido por Karl Marx. Para que um debate franco e produtivo possa ocorrer entre os diversos campos da filosofia do Direito é necessário que se explicite estas diferenças. O rigor deste tipo de filosofia depende, entre outras coisas, de se evitar qualquer tipo de ecletismo em que os autores distintos aparecem juntos - seja qual for o objetivo com o qual isso se dá - somente na medida em que são plenamente incompatíveis entre si. 


\section{REFERÊNCIAS}

CARLI, Ranieri. György Lukács e as origens históricas da sociologia de Max Weber. Rio de Janeiro: Lumen Juris, 2012.

CHASIN, José. Ensaios Ad Hominem, Tomo III - Política. São Paulo: Ensaio, 1999.

. Marx: Estatuto Ontológico e Resolução Metodológica. São Paulo: Boitempo, 2009.

CHAUI, Marilena. O que é ideologia? São Paulo: Brasiliense, 1979.

COTRIM, Lívia. A arma da crítica: política e emancipação humana na Nova Gazeta Renana. In: MARX, Karl. Nova Gazeta Renana. Trad. Lívia Cotrim. São Paulo: EDUC, 2010.

DOSSE, François. A História em Migalhas. Trad. Dulce A. Silva Ramos. Campinas, SP: Editora Universidade Estadual de Campinas, 1992.

ENGELS, Friedrich. Anti-Dühring. Rio de Janeiro: Paz e Terra, 1990.

Carta a Bebel de 18 a 28 de março de 1875. In: MARX, Karl. Crítica ao programa de Gotha. Trad. Rubens Enderle. São Paulo: Boitempo, 2012.

. Do socialismo utópico ao socialismo científico; Ludwig Feuerbach e o fim da filosofia clássica alemã. Trad. José Severo de C. Pereira. São Paulo: Fulgor, 1962.

; KAUTSKY, Karl. Juristen-Sozialismus. In: MARX, Karl; ENGELS, Friedrich. Werke. “Band 21”. Berlin: Dietz Verlag, 1962.

. O socialismo jurídico. Trad. Márcio Naves e Lívia Cotrim. São Paulo: Boitempo, 2012.

FORTES, Ronaldo Vielmi. As novas vias da ontologia em György Lukács: as bases ontológicas do conhecimento. Saardbrüeken: Novas Edições Acadêmicas, 2013.

GOMES, David; CATTONI DE OLIVEIRA, Marcelo Andrade. Constitucionalismo e dilemas da justiça. Belo Horizonte: Initia Via, 2014.

HONNETH, Axel. Reification: a new look to an old idea. Oxford: Oxford Press, 2012.

LOPES, Antonio José. A questão do Standpunkut na concepção de cientificidade marxiana. Revista On Line de Filosofia e Ciências Humanas, n. 12, Belo Horizonte, 2010.

LUKÁCS, György. Ontologia do ser social I. Trad. Nélio Schneider. São Paulo: Boitempo, 2012.

. Ontologia do ser social II. Trad. Nélio Schneider. São Paulo: Boitempo, 2013.

. Prolegômenos para uma Ontologia do Ser Social. Trad. Lya Luft e Rodnei Nascimento.

São Paulo: Boitempo, 2010.

Revista da Faculdade de Direito - UFPR, Curitiba, vol. 61, n. 2, maio/ago. 2016, p. 203 - 233 
MARX, Karl. A nova gazeta renana. Trad. Lívia Cotrim. Margem esquerda, 14, São Paulo, Boitempo, 2002.

. Contribuição à Crítica da Economia Política. Tradução Florestan Fernandes. São Paulo: Expressão Popular, 2009.

. Crítica à filosofia do Direito de Hegel - Introdução. In: MARX, Karl. Crítica à filosofia do Direito de Hegel. Trad. Rubens Enderle e Leonardo de Deus. São Paulo, Boitempo, 2005.

. Crítica ao programa de Goetha. Trad. Rubens Enderle. São Paulo: Boitempo, 2012.

. Das Kapital I. In: MARX, Karl; ENGELS, Friedrich. Werke. “Band 23”. Berlin: Dietz Verlag, 1968.

. Glosas Críticas Marginais ao Artigo “O Rei da Prússia e a Reforma Social” de Um Prussiano. São Paulo: Expressão Popular, 2010a.

. Grundrisse der Kritik der politichen ökonomie. Berlin: Dietz Verlag, 1953.

. Guerra Civil na França. Trad. Rubens Enderle. São Paulo: Boitempo, 2011.

. Kritik des Goethaer Programms. In: MARX, Karl; ENGELS, Friedrich. Werke. "Band 19”. Berlin: Dietz Verlag, 1962.

. Manuscritos econômico-filosóficos. Trad. Jesus Ranieri. São Paulo: Boitempo, 2004.

. Nova Gazeta Renana. Trad. Lívia Cotrim. São Paulo: EDUC, 2010c.

1988.

. O Capital, Volume I. Trad. Regis Barbosa e Flávio R. Kothe. São Paulo: Nova Cultural, 1987.

. O Capital, Volume II. Trad. Regis Barbosa e Flávio R. Kothe. São Paulo: Nova Cultural, . Sobre a Questão Judaica. Trad. Nélio Schneider. São Paulo: Boitempo, 2010b.

. Zur juden Frague. In: MARX, Karl; ENGELS, Friedrich. Werke. "Band 1”. Berlin: Dietz Verlag, 1976.

; ENGELS, Friedrich. A sagrada família. Trad. Marcelo Backers. São Paulo: Boitempo, 2003.

. Cultura, arte e literatura: textos escolhidos. Trad. José Paulo Netto. São Paulo: Expressão Popular, 2010.

. Die deutsche Ideologie. In: MARX, Karl; ENGELS, Friedrich. Werke. "Band 3”. Berlin: Dietz Verlag, 1968.

. Die heilige Familie. In: MARX, Karl; ENGELS, Friedrich. Werke. "Band 2”. Berlin: Dietz Verlag, 1972. 
. Ideologia alemã. Trad. Luís Claudio de Castro e Costa. São Paulo: Martins Fontes, 2002.

. Ideologia alemã. Trad. Rubens Enderle. São Paulo: Boitempo, 2007.

. Manifesto Comunista. Trad. Álvaro Pina e Ivana Jikings. São Paulo: Boitempo, 1998a.

. O Manifesto Comunista. Trad. Maria Lucia Como. Rio de Janeiro: Paz e Terra, 1998b.

MUSSE, Ricardo. O primeiro marxista. In: BOITO JUNIOR, Armando et al. (Org.). A obra teórica de Marx: atualidade, problemas e interpretações. São Paulo: IFCH/Xamã, 2002.

NAVES, Márcio Bilharinho. A questão do direito em Marx. São Paulo: Expressão Popular, 2014.

. Marxismo e Direito: um estudo sobre Pachukanis. Boitempo: São Paulo, 2000.

PAÇO CUNHA, Elcemir. Considerações sobre a determinação da forma jurídica a partir da mercadoria. Crítica do Direito, n. 64, São Paulo, 2014.

Engels como marxólogo. Revista On Line de Filosofia e Ciências Humanas, n. 20, Belo Horizonte, 2015.

SARTORI, Vitor Bartoletti. A atualidade da crítica de Marx e Lukács ao Direito. Direito e práxis, n. 9, Rio de Janeiro, UFRJ, 2014b.

A questão da crítica ao Direito à luz da obra madura de György Lukác. In: TORRIGLIA, Patrícia Laura et al. Ontologia e crítica do tempo presente. Santa Catarina: Em Debate, 2015d.

. Apontamentos sobre dialética e história em Friedrich Engels. Revista On Line de Filosofia e Ciências Humanas, n. 20, Belo Horizonte, 2015a.

- Apontamentos sobre Estado, sociedade civil-burguesa e revolução em Marx. Verinotio: Revista On Line de Filosofia e Ciências Humanas, n. 14, Belo Horizonte, 2012.

. Considerações sobre transformação social e Direito em Marx e Engels: sobre a necessidade de uma crítica decidida ao “terreno do Direito”. In: LIPPSTEIN, Daniela; GIACOBBO, Guilherme; MOREIRA, Rafael Bueno da Rosa. Políticas públicas, espaço local e marxismo. Santa Cruz do Sul: Essere del Mondo, 2015c.

. De Hegel a Marx: da inflexão ontológica à antítese direta. Kriterion, n. 130, Belo Horizonte, 2014a.

. Lukács e a crítica ontológica ao Direito. São Paulo: Cortez, 2010.

. Marx, marxismo e o terreno do Direito: um debate necessário. Verinotio: Revista On Line de Filosofia e Ciências Humanas, n. 19, Belo Horizonte, 2015b.

. Teoria geral do direito e marxismo de Pachukanis como crítica marxista ao direito.

Verinotio: Revista On Line de Filosofia e Ciências Humanas, n. 19, Belo Horizonte, 2015. 
VAISMAN, Ester. A ideologia e sua determinação ontológica. Verinotio: Revista On Line de Educação e Ciências Humanas, n. 12, Belo Horizonte, 2010.

\title{
LAW, POLITICS AND ACKNOWLEDGMENT: NOTES ON MARX AND THE CRITIC OF
} LAW

\begin{abstract}
Taking in account the Marxian affirmation that says that "Law is nothing else than the official acknowledgment of the fact", we intend to deal with the relationship between Law and acknowledgment (Anerkennung), having in mind the heterogeneity of Politics and Law. The first may present itself as a field more likely to make explicit the contradictions of bourgeois civil society (bürguerliche Gesellschaft), mainly centered in class struggle; Law, on the other hand, according to Marx, tends to be a field in which this is much less likely to occur.
\end{abstract}

\section{KEYWORDS}

Marx. Law. Acknowledgment. Politics. 